\title{
Comparative study of various renewable fuels blends to run a diesel power plant.
}

\author{
Eloisa Torres-Jimenez ${ }^{1}$, Marta Svoljšak Jerman ${ }^{2}$, Andreja Gregorc ${ }^{2}$, M. P. Dorado ${ }^{3}$, \\ Breda Kegl ${ }^{4}$ \\ ${ }^{1}$ Dep. Mechanics and Mining Engineering \\ E.T.S. University of Jaen \\ C/ Alfonso X el Sabio, 23700 Linares, Jaen, (Spain) \\ Phone/Fax number: +0034 953 648526/+0034953 212870, e-mail: etorres@ujaen.es \\ ${ }^{2}$ Petrol d.d. \\ Ljubljana, Dunajska 50, SI-1527 Ljubljana (Slovenia) \\ Phone/Fax number: +386(0)1 5863 459/+386(0)1 5863 502, e-mail: marta.slovoljsak@petrol.si, \\ andreja.gregorc@petrol.si \\ ${ }^{3}$ Dep. of Chemical Physics and Applied Thermodynamics \\ EPS, Ed Leonardo da Vinci, Campus de Rabanales, Universidad de Cordoba, 14071 Cordoba (Spain) \\ Phone/Fax number: +34 957 218332/+34 957 218417, e-mail: pilar.dorado@uco.es \\ ${ }^{4}$ Faculty of Mechanical Engineering \\ University of Maribor, Smetanova 17, SI-2000 Maribor (Slovenia) \\ Phone/Fax number: (02) 220 7732, e-mail: breda.kegl@uni-mb.si
}

\begin{abstract}
.
In this paper bioethanol/diesel and bioethanol/biodiesel blends, at several concentrations and temperatures, are studied to find its possible commercial usage as a fuel to run a diesel power plant.

The tested fuels were: net mineral diesel fuel (D100), $5 \%$ bioethanol/diesel fuel blend (v/v) (E5D95), $10 \%$ bioethanol/diesel fuel blend (v/v) (E10D90), $15 \%$ bioethanol/diesel fuel blend (v/v) (E15D85), neat biodiesel (B100), $5 \%$ bioethanol/biodiesel blend (v/v) (E5B95), $10 \%$ bioethanol/biodiesel blend (v/v) (E10B90), and $15 \%$ bioethanol/biodiesel blend $(\mathrm{v} / \mathrm{v})(\mathrm{E} 15 \mathrm{~B} 85)$. The fuels were tested at: $30,25,8$ and $-18^{\circ} \mathrm{C}$.
\end{abstract}

This paper shows the observations done in 8 samples during 5 weeks. After each week, each sample was overviewed, and changes related to stability, colour and aggregation were recorded.

It has been proved that additives are not necessary to ensure stability of bioethanol/biodiesel blends under low temperature conditions, as the phase separation never happens. But in case of bioethanol/diesel blends some additives are necessary to keep stability under low temperature conditions.

Based on this study, it can be concluded that blends of biodiesel fuel with bioethanol up to $15 \%$ can be used to fuel a diesel power plant if engine performance tests corroborate it. The same conclusion can be applied to blends of diesel fuel with bioethanol up to $15 \%$ blends if additives to keep stability are added.

\section{Key words}

Alternative fuel, biodiesel, bioethanol, heat engines, fuels blend.

\section{Introduction}

Nowadays the usage of biofuels is widely extended in the energy field. Biodiesel is Europe's dominant renewable fuel. In 2007 represented 90 percent of global production. By 2010, APPA Biocarburantes estimates that biodiesel production capacity in Spain will be 6.9 million tonnes annually, with a total of 67 manufacturing sites.

The most common biofuels today are biodiesel (made from vegetable oils) and bioethanol (made from sugar and starch crops).

Biodiesel is a biofuel widely studied. Researches are continuing improving this biofuel from the point of view of new row materials and low productions cost. It is usually produced from oleaginous crops, such as rapeseed, soybean, sunflower and palm, but actually new raw materials are being investigated as for example microalgae [1]. 
Ethanol can be produced from biomass by fermentation of sugar, by converting the starch content of biomass feedstocks into alcohol or by hydration of ethylene which is obtained from petroleum and other sources. The sugarcontaining raw materials are e.g. sugar cane, sugar beet, molasses and sweet sorghum. Starch can be found in very common crops such as corn, potatoes, and wheat.

Nowadays most of the ethanol produced (about 95\%) comes from the starch or sugar (bioethanol) in a wide variety of crops, but there has been considerable debate about the usage of ethanol made from edible material. In this sense recent developments with cellulosic ethanol production may allay some of these concerns.

Research is under way to commercialise "secondgeneration" production techniques that can make biofuels from woody material, grasses and some additional types of waste.

Biofuels are defined as: "transport fuels made from organic material". But biofuels can also run a dieselpower-plant (or diesel generator), so it could contribute to the electricity generation from renewable energy sources, as they are produced from biomass. Biomass energy along with wind, solar, geothermal, wave, tidal, hydropower, landfill gas, sewage treatment plant gas and biogases are defined as renewable energies under the European Directive 2001/77/EC [2].

A diesel generator is the combination of a diesel engine with an electrical generator (often called an alternator) to generate electric energy. Diesel generating sets are used in places without connection to the power grid or as emergency power-supply if the grid fails. Small portable diesel generators range from about $1 \mathrm{kVA}$ to $10 \mathrm{kVA}$ may be used as power supplies on construction sites, or as auxiliary power for vehicles such as mobile homes.

The promotion of electricity produced from renewable energy sources is a high Community priority as outlined in the White Paper on Renewable Energy, for reasons of security and diversification of energy supply, of environmental protection and of social and economic cohesion.

Biofuels are today the only direct substitute for oil in internal combustion engines that are available on a significant scale. Biodiesel is the only fuel that can be used in an ordinary diesel combustion engine, i.e. in a diesel engine not technically modified or manipulated.

Bioalcohols are usually blended with gasoline with good results. But alcohols blended with mineral diesel, as for example ethanol, can also run a diesel engine.

Bioethanol is an alternative fuel which has the advantages of being a renewable bio-based resource and its chemical composition lead to think that it has the potential to reduce harmful emissions.

Several studies have showed that biodiesel burns in a diesel engine, with much less total hydrocarbons (THC), carbon monoxide $(\mathrm{CO})$ and particulate matter $(\mathrm{PM})$ in the exhaust, although there was an increase in nitrogen oxides $\left(\mathrm{NO}_{\mathrm{x}}\right)$ [3][4][5][6]. In case of bioethanol-diesel blends, also PM in exhaust decreased substantially and slightly decrease was observed in $\mathrm{NO}_{\mathrm{x}}$. The effect on $\mathrm{CO}$ and THC are less clear although both were still well below the regulated emissions limit [7][8][9].

When two different fuels are going to be blended, their chemical composition can leads to some problems related to phase separation and fuel usage at low temperatures. Fuel stability influences fuel injection and combustion processes. Fuel blends must remain homogeneous over the time; else different fuels (as many as components constitute the blend) may be injected into the cylinder, affecting engine characteristics. Those problems justify a previous stability test before engine-performance and emissions characteristic tests, in order to determine if different fuels are being introduced in the combustion chamber which, in this case, would deteriorate the combustion process.

In this work we present the idea of blending bioethanol with diesel and biodiesel, as a way to decrease harmful emissions and to solve the problem of the increasing nitrogen oxides content in exhaust emissions when biodiesel is brunt in a compression ignition engine, always compared to those of diesel fuel. Future works will try to corroborate this supposition, but at the beginning of this research a study of fuel stability is needed.

\section{Materials}

Stability of 8 samples was determined. The tested samples were net mineral diesel fuel (D100) , $5 \%$ bioethanol/diesel fuel blend (v/v) (E5D95), $10 \%$ bioethanol/diesel fuel blend (v/v) (E10D90), $15 \%$ bioethanol/diesel fuel blend (v/v) (E15D85), neat biodiesel (B100), $5 \%$ bioethanol/biodiesel blend (v/v) (E5B95), $10 \%$ bioethanol/biodiesel blend (v/v) (E10B90), and $15 \%$ bioethanol/biodiesel blend (v/v) (E15B85).

Diesel fuel without additives was purchased from gasoline station Petrol d.d. Ljubljana (Slovenia), and its properties are shown in Table I.

The used biodiesel was purchased from Biogoriva d.o.o (Slovenia). It was produced from rapeseed oil and its characteristics are presented in Table II. According to this, the purity of the tested biodiesel is guaranteed as the ester content is higher than the minimum value prescribed by the biodiesel standard EN14214.

The used bioethanol was purchased from Carlo Erba Company (Milano - Italy); it was produced from the fermentation of sugars and its main properties are shown in Table III. 
Table I. - Properties of diesel fuel

\begin{tabular}{|c|c|c|c|}
\hline Property & Unit & $\begin{array}{c}\text { EN 590 } \\
\text { Min/Max }\end{array}$ & D100 \\
\hline Density at $15^{\circ} \mathrm{C}$ & $\mathrm{kg} / \mathrm{m}^{3}$ & $820 / 845$ & 837.3 \\
\hline $\begin{array}{l}\text { Cold filter plugging point } \\
\text { (Seasonal specification) }\end{array}$ & ${ }^{\circ} \mathrm{C}$ & $\begin{array}{l}\text { Max. Grade: } \\
A=+5, B=0 \\
C=-5, D=-10 \\
E=-15, F=-20\end{array}$ & -8 \\
\hline $\begin{array}{l}\text { Cloud Point } \\
\text { (only limited for artic } \\
\text { winters) }\end{array}$ & ${ }^{\circ} \mathrm{C}$ & $\begin{array}{l}\text { Max. Class: } \\
0=-10,1=-16 \\
2=-22,3=-28 \\
4=-34\end{array}$ & -3 \\
\hline Distillation & & & \\
\hline $50 \% \mathrm{~V} / \mathrm{V}$ & $\begin{array}{l}{ }^{\circ} \mathrm{C} \\
{ }^{\circ} \mathrm{C}\end{array}$ & Min. 85 & $\begin{array}{l}269.5 \\
333.6\end{array}$ \\
\hline Flash point & ${ }^{\circ} \mathrm{C}$ & $>55$ & 66.0 \\
\hline Lubricity - MWSD & $\mu \mathrm{m}$ & Max. 460 & 448.0 \\
\hline Cetane index & - & Min. 46 & 51.8 \\
\hline $\begin{array}{l}\text { Kinematic Viscosity (40 } \\
\left.{ }^{\circ} \mathrm{C}\right)\end{array}$ & $\mathrm{mm}^{2} / \mathrm{s}$ & $2 / 4.5$ & 2.8 \\
\hline Neat calorific value & $\mathrm{MJ} / \mathrm{kg}$ & - & 42.91 \\
\hline Water content & $\mathrm{mg} / \mathrm{kg}$ & Max. 200 & 50 \\
\hline $\begin{array}{l}\text { Corrosion } \\
\mathrm{Cu}, 3 \text { h at } 50^{\circ} \mathrm{C}\end{array}$ & Rating & Class 1 & $1 \mathrm{a}$ \\
\hline
\end{tabular}

Table II. - Properties of Biodiesel fuel

\begin{tabular}{|c|c|c|c|}
\hline Property & Unit & $\begin{array}{l}\text { EN } 14214 \\
\text { Min/Max }\end{array}$ & B100 \\
\hline Density at $15^{\circ} \mathrm{C}$ & $\mathrm{kg} / \mathrm{m}^{3}$ & $860 / 900$ & 882.6 \\
\hline $\begin{array}{l}\text { Cold filter } \\
\text { plugging point } \\
\text { (Seasonal } \\
\text { specification) }\end{array}$ & ${ }^{\circ} \mathrm{C}$ & $\begin{array}{c}\text { Max.: } \\
A=+5, B=0 \\
C=-5, D=-10 \\
E=-15, F=-20\end{array}$ & -10 \\
\hline Flash point & ${ }^{\circ} \mathrm{C}$ & Min. 120 & 138.5 \\
\hline Sulfated ash & $\%(\mathrm{~m} / \mathrm{m})$ & Max. 0.02 & $<0.02$ \\
\hline Iodine number & $\mathrm{g}$ Iodine/100 g & Max. 120 & 112 \\
\hline Acidity number & $\mathrm{mg} \mathrm{KOH} / \mathrm{g}$ & Max. 0.5 & 0.27 \\
\hline Ester content & $\%(\mathrm{~m} / \mathrm{m})$ & Min. 96.5 & 97.3 \\
\hline $\begin{array}{l}\text { Linolenic acid } \\
\text { methyl ester }\end{array}$ & $\%(\mathrm{~m} / \mathrm{m})$ & Max. 12.0 & 6.8 \\
\hline Methanol & $\%(\mathrm{~m} / \mathrm{m})$ & Max. 0.20 & $<0.01$ \\
\hline Phosphorus & $\mathrm{mg} / \mathrm{kg}$ & Max. 10.0 & $<5$ \\
\hline $\begin{array}{l}\text { Oxidation } \\
\text { stability, } 110^{\circ} \mathrm{C}\end{array}$ & $\mathrm{h}$ & Min. 6 & 9.8 \\
\hline Monoglycerides & $\%(\mathrm{~m} / \mathrm{m})$ & Max. 0.8 & 0.590 \\
\hline Diglycerides & $\%(\mathrm{~m} / \mathrm{m})$ & Max. 0.20 & 0.138 \\
\hline Triglycerides & $\%(\mathrm{~m} / \mathrm{m})$ & Max. 0.20 & $<0.050$ \\
\hline Free glycerol & $\%(\mathrm{~m} / \mathrm{m})$ & Max. 0.02 & 0.006 \\
\hline Total glycerol & $\%(\mathrm{~m} / \mathrm{m})$ & Max. 0.25 & 0.176 \\
\hline Water content & $\mathrm{mg} / \mathrm{kg}$ & Max. 500 & 150 \\
\hline Solid impurities & $\mathrm{mg} / \mathrm{kg}$ & Max. 24 & 14 \\
\hline $\begin{array}{l}\text { Sulphur content, } \\
\text { WD-XRF }\end{array}$ & $\mathrm{mg} / \mathrm{kg}$ & Max. 10 & 5.8 \\
\hline $\begin{array}{l}\text { Kinematic } \\
\text { viscosity at } 40^{\circ} \mathrm{C}\end{array}$ & $\mathrm{mm}^{2} / \mathrm{s}$ & $3.5 / 5$ & 4.477 \\
\hline Carbon residue & $\%(\mathrm{~m} / \mathrm{m})$ & Max. 0.30 & 0.21 \\
\hline $\begin{array}{l}\text { Corrosion } \\
\mathrm{Cu}, 3 \mathrm{~h} \text { at } 50^{\circ} \mathrm{C}\end{array}$ & classification & 1 & $1 \mathrm{a}$ \\
\hline
\end{tabular}

Table III. - Bioethanol $\left(\mathrm{C}_{2} \mathrm{H}_{5} \mathrm{OH}\right)$ properties (ISO 9001)

\begin{tabular}{lccc}
\multicolumn{1}{c}{ Property } & Unit & Specification & Result \\
\hline $\begin{array}{l}\text { Assay at } 20^{\circ} \mathrm{C} \\
\text { (Purity) }\end{array}$ & $\%(\mathrm{v} / \mathrm{v})$ & $>=99.8$ & 99.9 \\
$\begin{array}{l}\text { Boiling Point } \\
\text { Density at } 20^{\circ} / 4^{\circ}\end{array}$ & ${ }^{\circ} \mathrm{C}$ & Min 78.3/Max 78.8 & 78.5 \\
& - & Min 0.790/Max & 0,791 \\
Water content & $\%$ & 0.793 & \\
& & $<=0.2$ & 0.04 \\
\hline
\end{tabular}

\section{Methodological process}

Fuel stability test is performed in order to determine if additional mixing, additives or heating (in case low temperatures produce solid aggregation of the fuel) are necessary.

The samples were tested at: $25^{\circ} \mathrm{C}$ (ambient temperature), $+30^{\circ} \mathrm{C}$ (representative temperature of summer), $+8^{\circ} \mathrm{C}$ (representative temperature of not critical winter), and $-18^{\circ} \mathrm{C}$ (temperature at which certainly the samples were solid). Each sample was checked once a week during a 5 week period; we estimate that this is enough time to get to know its behaviour in long periods of storage. After each week the observations about each sample were recorded according the following points:

1) Sample stability: 1 or 2 layers.

2) Sample state: liquid or solid phase.

3) Sample color: no changes, lighter or darker than previous observation.

\section{Results and discussion}

\section{A. Bioethanol/diesel blends}

Results are depicted in Table IV. Below $8^{\circ} \mathrm{C}$ all bioethanol/diesel fuel blends separate in two phases. Only samples tested above $25^{\circ} \mathrm{C}$ remain in one phase. It means that phase separation starts between 8 and $25^{\circ} \mathrm{C}$. To determine the exact point at which it occurs more stability test are needed.

Table IV. Fuel stability and phase separation of diesel fuel and bioethanol/diesel fuel blends during 5 weeks observation.

\begin{tabular}{|c|c|c|c|c|}
\hline \multirow{2}{*}{ Fuel } & \multicolumn{4}{|c|}{ Testing temperature $\left({ }^{\circ} \mathrm{C}\right)$} \\
\hline & 30 & 25 & 8 & -18 \\
\hline D100 & \multirow[t]{4}{*}{$\begin{array}{l}\text { Stability: } \\
* \text { NC. } 1 \\
\text { layer } \\
\text { State: } \\
\text { liquid } \\
\text { Colour: } \\
* N C\end{array}$} & $\begin{array}{l}\text { Stability: } \\
\text { *NC. 1 layer } \\
\text { State: liquid } \\
\text { Colour: After } \\
2 \text { weeks, little } \\
\text { less clear }\end{array}$ & \multirow[t]{2}{*}{$\begin{array}{l}\text { Stability: } \\
* \text { NC. } 1 \\
\text { layer } \\
\text { State: } \\
\text { liquid } \\
\text { Colour: } \\
* N C\end{array}$} & $\begin{array}{l}\text { Stability: } \\
\text { *NC. } 1 \text { layer } \\
\text { After } 5 \text { weeks, } \\
2 \text { layers. } \\
\text { State: After } 2 \\
\text { weeks some } \\
\text { solid parts in } \\
\text { liquid fuel. } \\
\text { Colour: } * N C\end{array}$ \\
\hline E05D95 & & \multirow{3}{*}{$\begin{array}{l}\text { Stability: } \\
\text { After } 4 \\
\text { weeks, } \approx 10 \% \\
\text { of bioethanol } \\
\text { was } \\
\text { separated. } \\
\text { After } 5 \\
\text { weeks, some } \\
\text { bubbles at the } \\
\text { surface } \\
\text { State: liquid } \\
\text { Colour: } * N C\end{array}$} & & \multirow{3}{*}{$\begin{array}{l}\text { Stability: After } \\
5 \text { weeks, } 3 \\
\text { layers: } \\
\text { bioethanol + } 2 \\
\text { layers in diesel } \\
\text { fuel. } \\
\text { State: After } 1 \\
\text { week, } 2 \text { phases } \\
\text { (liquid with } \\
\text { some solid } \\
\text { parts) } \\
\text { Colour: } * N C\end{array}$} \\
\hline E10D90 & & & Stability: & \\
\hline E15D85 & & & $\begin{array}{l}\text { weeks, } 2 \\
\text { layers } \\
\text { State: } \\
\text { liquid } \\
\text { Colour: } \\
* N C\end{array}$ & \\
\hline
\end{tabular}

\section{*NC: No changes}

To preserve stability, additives for bioethanol/diesel fuel blends are needed. Previous researches have demonstrated that the presence of water in the blends, low temperatures and high ethanol contents favor the 
phase separation whereas the presence of additives leads to the opposite effect [10][11]. Nowadays these kinds of additives are increasing as long as energy sources become cleaner and renewable [12]. The optimal choice of additives depends on ethanol concentration and climate where the blend will be used. So this statement justifies further studies to determine the best additives for the blends under study.

The photographs in figure 1 show some of the results recorded in table IV about bioethanol/diesel blends:

1) Photograph 1.a: No changes in stability, colour and aggregation.

2) Photograph 1.b and 1.c: bioethanol separates from diesel fuel, see bioethanol bubbles travelling to the surface.

3) Photograph 1.d: at $+8{ }^{\circ} \mathrm{C}$ bioethanol separates from diesel fuel. Two layers are observed.

4) Photograph 1.e: at $-18{ }^{\circ} \mathrm{C}, 3$ layers are observed in E15D85 blend (2 layers in diesel fuel).
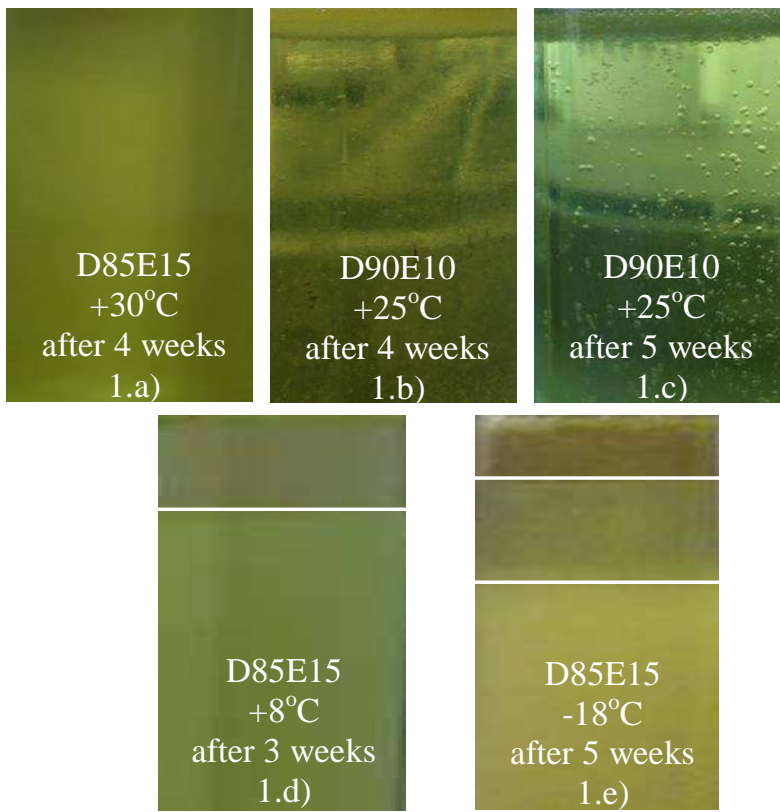

Figure 1 - Stability. Bioethanol-diesel fuel blends.

\section{B. Bioethanol/biodiesel blends}

According to results shown in Table $\mathrm{V}$, all bioethanol/biodiesel blends remain in one phase regardless of temperature and bioethanol concentration. Only at $-18^{\circ} \mathrm{C}$ all samples are solid.

When B100 warms up and becomes liquid, some white particles can be easily seen (see 2.a). These particles are paraffins. In case of bioethanol/biodiesel blends, bioethanol changes the melting process in such a way that paraffins are different in size and shape; effectively the paraffins are not visible (see 2.b). Invisible paraffins lead to an improvement from the point of view of winter properties, such us cloud point and cold filter plugging point, because these properties are linked to the moment in which paraffins appears during the solidification process. Similar behaviour was observed during subsequent observations. Therefore, bioethanol acts as a winter additive. Bioethanol/biodiesel blends need less time to become liquid than B100.

Table V. - Biodiesel and bioethanol/biodiesel blends stability during 5 weeks observation

\begin{tabular}{|c|c|c|c|}
\hline \multirow{2}{*}{ Fuel } & \multicolumn{3}{|c|}{ Testing temperature $\left({ }^{\circ} \mathrm{C}\right)$} \\
\hline & 25 & 8 & -18 \\
\hline B100 & $\begin{array}{l}\text { Stability: } \\
\text { *NC. } 1 \text { layer } \\
\text { State: liquid } \\
\text { Colour: *NC }\end{array}$ & $\begin{array}{l}\text { Stability: } \\
\text { *NC. } 1 \text { layer } \\
\text { State: liquid. } \\
\text { After } 3 \\
\text { weeks, } \\
\text { higher } \\
\text { viscosity } \\
\text { Colour: *NC }\end{array}$ & $\begin{array}{l}\text { Stability: } \\
\text { *NC. } 1 \text { layer } \\
\text { State: After } 1 \\
\text { week, completely } \\
\text { solid. During } \\
\text { melting process } \\
\text { paraffins are } \\
\text { visible. } \\
\text { Colour: lightly } \\
\text { intensified. }\end{array}$ \\
\hline E05B95 & \multirow{3}{*}{\multicolumn{2}{|c|}{$\begin{array}{l}\text { Stability: } * \mathrm{NC} .1 \text { layer } \\
\text { State: liquid } \\
\text { Colour: } * \mathrm{NC}\end{array}$}} & Stability: *NC. 1 \\
\hline E10B90 & & & layer \\
\hline E15B85 & & & $\begin{array}{l}\text { State: After } 1 \\
\text { week, completely } \\
\text { solid. During } \\
\text { melting process } \\
\text { paraffins are not } \\
\text { visible. } \\
\text { Colour: lightly } \\
\text { intensified. }\end{array}$ \\
\hline
\end{tabular}

*NC: No changes

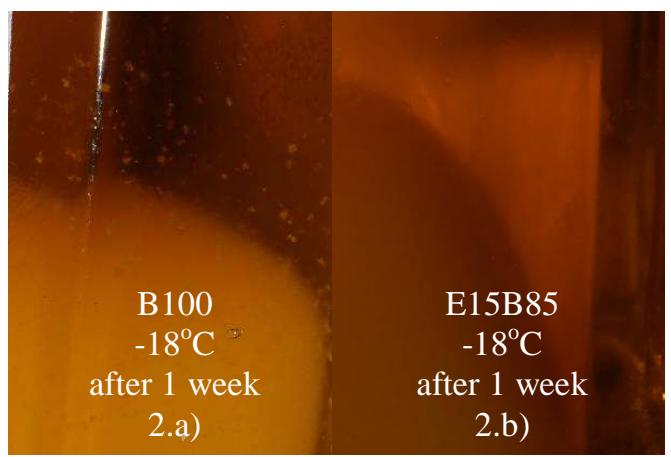

Figure 2. a) Paraffins in pure biodiesel during melting process.

b) Paraffins are not visible in bioethanol/biodiesel blends

The photographs in figure 3 show some of the results recorded in table $\mathrm{V}$ about bioethanol/biodiesel blends:

1) Photographs 3.a, 3.b and 3.c: No changes in stability, colour and aggregation. One phase, so no problems related to stability.

2) Photograph 3.d: all blends tested solidify at low temperatures $\left(-18{ }^{\circ} \mathrm{C}\right)$. This photograph was taken during the melting process to be able to see that the sample was solid and colour was lightly intensified.
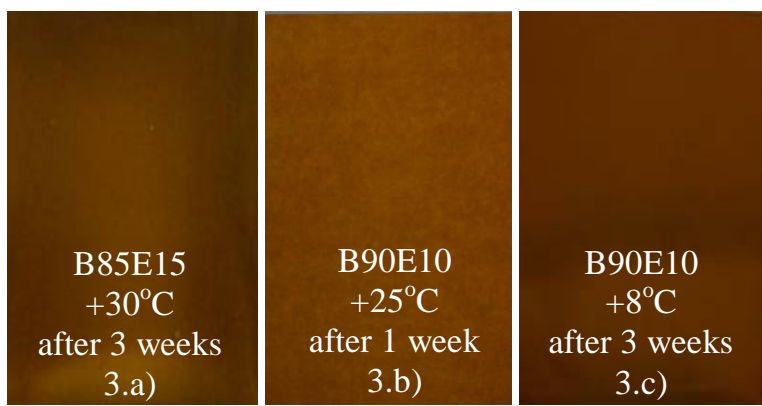

Figure 3.a, 3.b and 3.c - Stability. Bioethanol-biodiesel blends. 


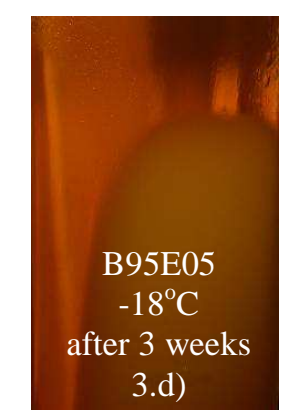

Figure 3.c and 3.d - Stability. Bioethanol-biodiesel blends.

\section{Conclusion}

In the present work, it has been proved that additives are not necessary to ensure stability of bioethanol/biodiesel blends under low temperature conditions, as the phase separation never happens. Generally, adding bioethanol to biodiesel improves biodiesel usage, because pure biodiesel needs more time to melt down than biodiesel blended with bioethanol, and because bioethanol decreases the size of paraffins leading to an improvement in the behaviour of the fuel at low temperatures.

In case of bioethanol/diesel fuel blends it has been proved that some additives are necessary to keep stability under low temperature conditions, as the fuels separation starts between 8 and $25^{\circ} \mathrm{C}$.

Based on this study, it can be concluded that blends of biodiesel fuel with bioethanol up to $15 \%$ can be used to fuel a diesel power plant if engine performance tests corroborate it. The same conclusion can be applied to blends of diesel fuel with bioethanol up to $15 \%$ blends if additives to keep stability are added.

\section{Acknowledgement}

This research was supported by the European Community's Sixth Framework Programme in the scope of the Civitas II Mobilis project. Authors are also grateful for the provision of a Research Mobility Grant to E. Torres-Jimenez from the University of Jaen, Spain.

\section{References}

[1] L. Gouveia, A. Cristina Oliveira, "Microalgaes as a row material for biofuels production", in Energy Conversion and Management, Vol. 47, pp. 32723287, 2006.

[2] European Directive 2001/77/EC of the European parliament and of the council, Promotion of electricity produced from renewable energy sources in the internal electricity market, 2001.

[3] B. Kegl, "Effects of biodiesel on emissions of a bus diesel engine", in Bioresour.Technol., Vol. 99, pp. 863-873, 2008.

[4] C.D. Rakopoulos, K.A. Antonopoulos, D.C. Rakopoulos, D.T. Hountalas, E.G. Giakoumis, "Comparative performance and emissions study of a direct injection Diesel engine using blends of Diesel fuel with vegetable oils or bio-diesels of various origins", in Energy Conversion and Management, Vol. 47, pp. 3272-3287, 2006. A.C.

[5] M.P. Dorado, E. Ballesteros J.M. Arnal, et al., "Exhaust emissions from a Diesel engine fueled with transesterified waste olive oil", in Fuel, Vol. 82, pp. 1311-1315, 2003.

[6] M.P. Dorado, E. Ballesteros J.M. Arnal, et al., "Testing waste olive oil methyl ester as a fuel in a diesel engine", in Energy \& Fuels, Vol. 17, pp. 1560-1565, 2003.

[7] A.C. Hansen, Q. Zhang, P.W.L. Lyne, "Ethanoldiesel fuel blends -a review", in Bioresource Technology, Vol. 96, pp. 277-85, 2005.

[8] M. Lapuerta, O. Armas, J.M. Herreros, "Emissions from a diesel-bioethanol blend in an automotive diesel engine", in Fuel Vol. 87, pp. 25-31, 2008.

[9] M.D. Kash, J.F. Thomas, J.M. Storey, N. Domingo, J. Wade, G. Kenreck, "Emissions from a 5.9 liter diesel engine fuelled with ethanol diesel blends", SAE Technical paper 2001-01-2018 (SP-1632), 2001.

[10] M. Lapuerta, O. Armas R. García-Contreras, "Stability of diesel-bioethanol blends for use in diesel engines", in Fuel, Vol. 86, pp. 1351-1357, 2007.

[11] Gerdes, K.R., Suppes, G.J., 2001, "Miscibility of ethanol in diesel fuels", in Ind. Eng. Chem. Res. Vol. 40, pp. 949-956, 2001.

[12] N.M. Ribeiro, A.C. Pinto, C.M. Quintella, G.O. da Rocha, L.S.G. Teixeira, L.L.N. Guarieiro, M. do Carmo Rangel, M.C.C. Veloso, M.J.C. Rezende, R. Serpa da Cruz, "The role of additives for diesel and diesel blended (ethanol or biodiesel) fuels: a review", in Energy Fuels, 2007, Vol. 21, pp. 24332445. 